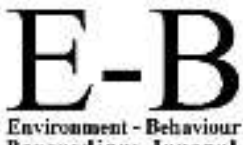

International Virtual Colloquium on Multi-disciplinary Research Impact $\left(1^{\text {st }}\right.$ Series $)$

Organised by Research Nexus UiTM (ReNeU)

Office of Deputy Vice Chancellor (Research and Innovation)

Universiti Teknologi MARA 40450 Shah Alam, Malaysia, 15 Oct 2021

\title{
Halal Food Delivery Services in Malaysia: Food hygiene and safety during Covid-19 pandemic
}

\author{
Hanifah Musa Fathullah Harun, Nurulaina Saidin, \\ Mohd Dasuqkhi Mohd Sirajuddin, Mohammad Mahyuddin Khalid
}

Academy Of Contemporary Islamic Studies,

Universiti Teknologi MARA, 40450 Shah Alam, Selangor

hanifah0704@uitm.edu.my, nurulainasaidin@uitm.edu.my, dasuqkhi@uitm.edu.my,emkay@uitm.edu.my Tel: 013-2112859

\begin{abstract}
Food delivery services are popular and have become a necessity among Malaysians, especially during the pandemic Covid-19. Nevertheless, there are several issues faced by food delivery services primarily related to halal status and food hygiene. Using qualitative research methodology, this paper attempts to identify issues related to halal food delivery and its integrity. The findings showed that there are notable issues related to the food industry and delivery services that could be overcome by adhering to the control procedures issued by the National Security Council (MKN) and Islamic principles under the purview of Maqasid Shariah.
\end{abstract}

Keywords: Covid-19, food delivery, food hygiene, halal

eISSN: 2398-4287 @ 2021. The Authors. Published for AMER ABRA cE-Bs by e-International Publishing House, Ltd., UK. This is an open access article under the CC BYNCND license (http://creativecommons.org/licenses/by-nc-nd/4.0/). Peer-review under responsibility of AMER (Association of Malaysian Environment-Behaviour Researchers), ABRA (Association of Behavioural Researchers on Asians) and cE-Bs (Centre for Environment-Behaviour Studies), Faculty of Architecture, Planning \& Surveying, Universiti Teknologi MARA, Malaysia.

DOI: https://doi.org/10.21834/ebpj.v6iSl6.3039

\subsection{Introduction}

Muslim consumers are known to have adequate knowledge of halal that incorporates every aspect of their lifestyle. They are commonly very sensitive and particular on the halal status of consumable products and possess an excellent understanding about halal food consumption. This awareness results from the Quran's encouragement, mentioned explicitly in surah al-Baqarah, verse 168, which commands all Muslims to choose halal and thoyyib food. Rasulullah PBUH said in the prominent hadith on halal: "Verily Allah has prescribed proficiency in everything. Thus, if you kill, you kill well: and if you slaughter, you need to slaughter well. Let each one of you sharpen his blade and let him spare suffering to the animal he slaughters" (Hadith Muslim). Food is considered halal when it fulfills several elements, such as does not consist of ingredients of prohibited animals, the animals are slaughtered according to Islamic rituals, and the tools used are free from najs during preparation, manufacturing, and storage (Department of Standards Malaysia, 2009).

Before the introduction of halal certification, Halal status was synonymous with food preparation made by Muslims, and Muslims perceived this kind of food product as guaranteed halal. During those times, people's trust in halal status depends much on how the traders and food providers attract the consumer in believing that the foods are halal. Hence, started in 1974, Malaysia has become a pioneer in halal certification through the appointment of the Research Centre for the Islamic Affairs Division as the government agency to issue halal certificates. It began a new revolution in 2000 when Malaysia transformed into the first nation to have a comprehensive halal assurance system implemented in the country (Islamic Tourism Centre, 2021). The Food and Islamic Consumer Products Division under The

eISSN: 2398-4287 @ 2021. The Authors. Published for AMER ABRA cE-Bs by e-International Publishing House, Ltd., UK. This is an open access article under the CC BYNCND license (http://creativecommons.org/licenses/by-nc-nd/4.0/). Peer-review under responsibility of AMER (Association of Malaysian Environment-Behaviour Researchers), ABRA (Association of Behavioural Researchers on Asians) and cE-Bs (Centre for Environment-Behaviour Studies), Faculty of Architecture, Planning \& Surveying, Universiti Teknologi MARA, Malaysia.

DOI: https://doi.org/10.21834/ebpj.v6iSI6.3039 
Department of Islamic Development Malaysia (JAKIM) has been mandated to observe all halal certification activities in 2002 (Halal Management Division of JAKIM, n.d.).

The development of halal is multiplying from year to year and has expanded to other products such a pharmaceuticals, premises, clothing, cosmetics, and services. Hence, Halal has been perceived as a build in approach in food-related services in this country where Muslim society believe that not only the food and beverages be halal, the related services including delivery should be conducted according to the Shariah perspective so that the delivered halal products are maintained as halal from the farm to the fork. The upsurge of necessities for food delivery services during the Covid-19 pandemic due to certain limitations and restrictions implemented in the country has created the need for halal and safe delivery services due to the huge demand of the Muslim society in this country. This study, therefore, was conducted to identify issues related to halal food delivery and its integrity, so that certain improvements and recommendations could be applied to rectify the issues.

\subsection{Literature Review}

\subsection{Food Delivery Services In Malaysia}

Recent global industrial growth in the food ordering and delivery market had shown significant financial gain worth approximately $€ 95$ billion, or 1 percent of the overall food market and 4 percent of food retailed through restaurants and fast-food chains. In many countries in the world, this industry has rapidly grown with an estimated total annual growth rate of 3.5 percent for the next five years. David (Tan 2019), in his study, has found that Malaysia's revenue for online food delivery was expected around US\$145mil (RM599mil) in 2019. However, a current report from Statista.com (2021) stated that the latest revenue in the Online Food Delivery market is estimated to reach US $\$ 271 \mathrm{~m}$ in 2021. The industry revenue is estimated to show an annual growth rate (CAGR 2021-2025) of 12.61 percent, proceeding with a projected market volume of US $\$ 435 \mathrm{~m}$ by the year 2025 .

According to Nina Naquiah Ahmad Nizar and Siti Aimi Sarah Zainal Abidin (2021), the traditional purchasing of food is only feasible by visiting food outlets in-person or calling food outlets directly to place orders before collection or delivery. With the advancement in innovation and technology, the modern practice is online ordering and conveyance benefit that utilizes third-party platforms. In Malaysia, food delivery services have become a phenomenon, and they started growing up in 2017. These outsource services become familiar and have a high demand because of the convenience of ordering and delivering. Besides that, these third-party food delivery service providers are popular due to lucrative revenues, wider customer reach, and an expanded customer base. According to Li et al. (2020), food delivery services can be divided into either restaurant to consumer delivery or platform to consumer delivery operations. Both categories of operations are also familiar in Malaysia. Restaurant to consumer delivery companies creates the food and delivery team provided by the company such as KFC, Pizza hut, Dominos, and McDonald's. Meanwhile, platform-to-consumer delivery companies primarily offer online delivery services from partner restaurants that do not possess delivery services.

There are several companies of food providers in Malaysia offering food delivery services such as Grabfood, Lalamove, FoodPanda, AirAsia Food, SmartBite, Dahmakan, Hungry, Pichaeats, DeliverEat, Meal in Minutes, RunningMan, Bungkusit, The Naked Lunchbox, Epic Food Hall, Shogun2U, Cooking Good and GoGet. Most customers choose these services, particularly those living in metropolitan regions and busy with their work. According to Chai \& Yat (2019), this is the main reason why delivery service providers are concentrated more in Kuala Lumpur, Selangor, Penang, and Johor Bharu.

It is impressive to see the Muslim consumers in Malaysia become more knowledgeable about halal and hygienic food intake. This concern derived from greater knowledge on halal food consumption and the important role of interactive platforms such as social media, news, radio, and other technology to convey halal-related information to customers. It could efficiently boost customers' awareness of halal and any product or service provided. Despite this covid-19 pandemic, the Muslim communities appeared to be more careful in ensuring that the food sold to them is halal, in which integrity and cleanliness are their main essential priorities in choosing food. They are also concerned about the safety and quality of food being delivered to them. It is common for consumers to refer to restaurant information updates or search engine portals on particular food service providers. For example, the restaurant owners will describe the food, types, and halal status criteria. Sometimes, the customer will choose the food based on the previous customer reviews and ratings. Besides, good on-time delivery (OTD) performance plays a significant role in clients' satisfaction and loyalty in online food ordering (Kedah, Zulkarnain, Ismail, et al., 2015).

Despite the rapid increase and demand for food delivery services among Muslims in Malaysia, limited research has been conducted related to the Halal aspect of this kind of service. Recent studies are concentrated more on customers satisfaction and intention to use online food delivery applications (Ahmad \& Lasi, 2020; Mat Nayan \& Hassan, 2020; Pitchay et al., 2021), factors affecting quality control of delivered food (Yuchen, 2020), and barriers of using third party online food delivery (Sin \& Lo, 2021). Hence, there are many issues on the Halal food and delivery services occurred that should be examined to help the industry to expand further in the future.

\subsection{Methodology}

This study employs a qualitative methodology where it incorporates data collected through library research. Several references utilized include sacred texts of the al-Quran and Hadith of the Prophet PBUH, classical works from the notable Muslim jurists connected to the halal food and delivery sector, and related journal articles on halal that draw insights on the subject of study. The research also used online resources for social sciences such as EBSCO, Academy Search Premier, ProQuest, and Science Direct. Hence, this research involves 
the combination of two or more types of methodologies namely the descriptive, explanatory, critical, and, also comparative approaches to analyze the perspectives of the scholars about food and delivery operations. The research flow for this study was stated in figure 1.

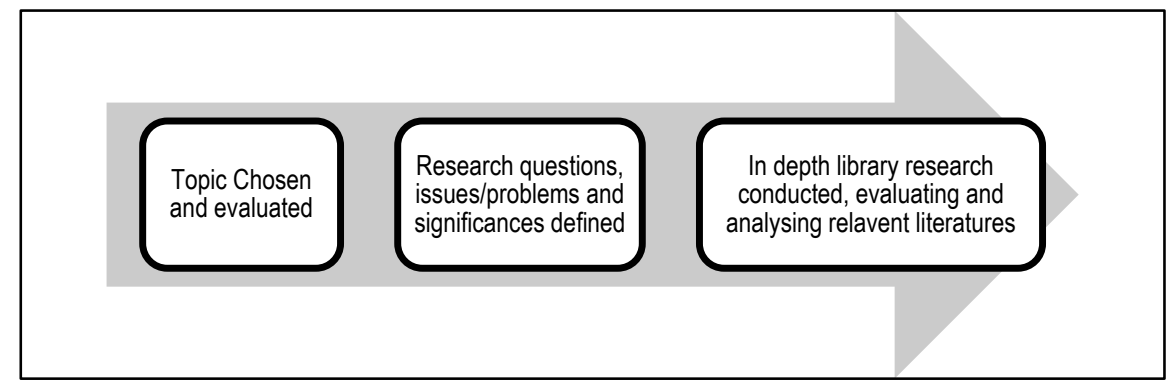

Fig. 1: Illustration of library research methodology flow utilised in the present study.

\subsection{Findings}

\subsection{Issues On Halal food and Delivery}

Under the previous Manual Procedures for Malaysia Halal Certification 2014 (MPPHM 2014) published by JAKIM, food delivery services providers may apply for halal certification (Jakim, 2014). Companies or chain restaurants with central kitchens preparing food and beverages before being sold to consumers could also apply for Halal certification. As such, the halal certificate will only be issued to the central kitchens upon compliance with all halal certification requirements and passing the audit process. With the introduction of the new MPPHM 2020, food delivery services owners may also apply for halal certification for their delivery services (Department of Islamic Development Malaysia (JAKIM), 2020). They are also required to have a Halal Assurance Management System in place. With this new development, it is pertinent for the owners and providers to have certain kinds of guidance and reference to manage food contamination, food safety, or halal risks.

Although Malaysia has its guideline on halal and certification, there are still issues related to the food in many ways, such as contaminated food from procurement, preparation, storage, and transportation. These repeatedly reported issues especially concerning cross-contamination of food need to be evaluated from the perspective of Shariah. Among the issues include intentional mislabelling of food products, contamination of halal meat with pork and other non-halal ingredients, halal meat certification, and illegal slaughter. There are a few conducted studies related to the malpractice that happened in the halal food industry as specified below:

i) Mislabelling the product containing non-halal ingredients such as pig blood and skin as halal (Fuseini et al., 2017). This study examined the concerns related to this issue. Even though the incident did not happen in Malaysia, and the company had already apologized to its Muslim buyers, this incident still had affected and inducing unfavorable consequences to the Muslims due to its connection with halal or haram status.

ii) Non-halal meat issue where 4 pork mix containers combined with a goat from Spain was uncovered by the Malaysian Quarantine and Inspection Service (MAQIS) during a raid in Port of Tanjung Pelepas (Nurul Amanina Suhaini, 2017).

ii) Cross-contamination of halal with non-halal ingredients due to improper control of halal food chain. The Sorisso restaurant and Pizzeria Company in Kampung Kiarong, Brunei Darussalam, violating the halal labeling 2005 standards by introducing questionable products (Sim Y. H., 2018).

iv) A rider revealed that one of the food vendors in Johor Bharu premises sells food using the Malay name store, although the owner is non-Muslim. This situation is not because of racist issues, but it is related to the Muslim consumer's halal and haram food status (Suhaniza Said, 2021).

v) A viral case of a rider crosses a large drain to deliver food to the customer, and the two boxes of pizza fall inside the drain due to an unzipped storage bag (Nabilah, 2021). Although these appear to be jokes or have no bearing on our communities, they are related to food safety and risk.

vi) A total of 99 victims were rushed to Hospital Sultanah Nur Zahirah (HSNZ) for vomiting and diarrhea after enjoying pudding purchased online (Baharom Bakar, 2021).

\subsection{Discussion}

Reviewing the issues of halal food delivery in the country, it is apparent that certain measures should be applied to improve the current condition. Hence, food production staff should adhere to the Manual Procedure for Malaysia Halal Certification 2020 (MPPHM 2020) by wearing appropriate attire and should always practice the code of ethics and Good Hygienic Practices (GHP) stated in the Food Hygiene Regulations 2009. This practice should always be observed not only by the workers but also by the management staff to ensure the safety and quality of food produced. All the production processes including the product movement, materials storage, and handling should be prioritized. This is supported by Noorsiah Ahmad \& Sariwati Mohd Shariff (2016) who claimed that contamination may occur during the moving process depending largely on the contingency of disclosure, a period of contact, and regular exposure to the halal products being carried. For instance, in the case of contaminations with najs mughallazah (dogs and pigs including any molecule liquid 
and also objects discharged), the workers involved in logistic operation need to be well versed and equipped with remedial preventive and corrective measures in maintaining the halal status of transport containers carrying the halal goods (MS2400: 2019).

In addition, there are several guidelines for P-hailing services delivery for food products prepared by the National Security Council (MKN) (2021) that should be implemented by those involved in the food delivery industries to ensure safe and hygienic food delivery without the risk of cross-contamination during the existing pandemic Covid-19 situation, as stipulated below:

i) All food vendors must adopt the required health, social distance, and contactless transaction policies. These also include wearing face masks, using hand sanitizer, and routinely washing hands after making a delivery

ii) According to the Health Ministry of Malaysia ( $\mathrm{MOH} / \mathrm{KKM})$, riders should ensure daily routine sanitation of delivery boxes.

iii) Delivery boxes utilized by p-hailing motorcycle riders must follow standard dimensions and be used as set by the RTD.

iv) The employer must fully assist the $\mathrm{MOH}$ to carry out contact tracing and management on the employee.

v) A rider with symptoms should immediately take the necessary precaution steps to self-isolate and stop providing delivery services.

vi) Only gazetted motorcycle lane could be used by the riders and whenever possible, the rider should wear visible attire.

vii) All p-hailing riders must download, install and register themselves under the mySejahtera app administered by NSC.

In Islam, the Islamic law (Shariah) has provided Muslims with essential guidelines and fundamental values suitable for the maslahah (best interest and benefit) of humankind. Shariah as comprehensive law comprise of a rich legal system that had been introduced and developed by the Muslim jurists and scholars, predominantly during the glory days. In later stages, this guided legal system had eventually been recognized as al-Figh al-Islami or Islamic law. The main sources of Islamic law are the Quran and the Hadith of the Prophet PBUH. In the Quran, there is no specific guidance related to the halal delivery operation, hence, most of the themes associated with halal are concentrating on the demand to obtain halal food and halal sources. Numerous Quranic verses clarify the aspects of halal and haram, especially in food consumption. However, it is important to note that the importance and necessity of halal understanding embedded from the Quran are not concentrated only on food but also expanded to other Muslim daily activities, including delivery operations.

Reviewing the contemporary opinion related to food delivery services, it was found that Irsyad Fatwa in 2017 had discussed generally related to the food delivery conditions (Mohamad Razif, 2017), as stated below:

"Food Deliveryman needs to examine the food/beverage ordered whether it is halal, haram or a mixture of halal and haram. If it is non-halal food or drink, it is also illegal for them to be involved in the delivery process. However, the fatwa also mentioned that if the order is mixed between halal and haram, three conditions need to be given attention:

i) If halal food and drink exceeds haram, we tend to state that the income is halal because the Prophet PBUH also used to trade with polytheists and ahlul kitab

ii) If the haram food or drink exceeds halal, then the income earned according to Imam Ahmad is better to be avoided unless it is minor or difficult to know or to be differentiated.

iii) The income is considered makruh if the delivery provider cannot distinguish between halal and haram food or drink".

According to the opinion given in the Irsyad Fatwa (Office of the mufti of the federal territory), it is pertinent to note that Muslim riders involved in the food delivery services should observe their daily working activities so as to ensure that they are not delivering non-halal food or products because these conducts can be considered as haram from the Islamic perspective and should be avoided.

\subsection{Conclusion \& Recommendations}

For Muslims, halal food delivery services is very essential in ensuring the food delivered to the consumer is clean, safe, and halal. The findings of the study have included current issues in the food delivery services in the country which among others comprise of safety, quality and halal issues. This study had also elaborated a few measures that had been taken by the authorities and could be applied by the food delivery services provider, in order to improve their services, especially during the pandemic Covid-19. Hence, certain aspects could not be explained in this study, especially on risks assessment related to halal and safety during delivery that should also be prioritised by the industry players. Further study should therefore be conducted on this particular issue. Based on the disputable cases in these issues, we believe that there are two aspects that need to be paid attention to. Firstly, food providers and food delivery service providers should learn how to handle food and be aware of halal and food safety risks during the preparation and delivery. Proper Islamic training is needed to enhance their knowledge in complying with high-quality assurance. A good understanding of the principle of Shariah can increase the confidence level of the food providers and also the consumers. Secondly, those in charge of food need to be extra careful on hygiene, food ingredients, expired dates, storage, and food temperature because any misconduct in managing foods may lead to the possibility of food poisoning or death.

\section{Acknowledgment}

The researchers gratefully acknowledge the full support and encouragement of the Academy Contemporary of Islamic Studies, Universiti Teknologi MARA, International Institute for Halal Research and Training (INHART), International Islamic University Malaysia, and the family members in publishing this paper. 


\section{References}

Ahmad, M. A., \& Lasi, A. (2020). The Attitudes on Consumer Perceptions towards Viral Marketing: A Study on Foodpanda Food Delivery in Malaysia. International Journal of Research and Scientific Innovation (IJRSI) |, VII.

Anna Freer. (2020, September 2). Food delivery apps have a customer service issue. Businessofapps.Com.

Aslı Uçar, M. V. Y. and F. P. Ç. (2016). FOOD SAFETY- PROBLEM AND SOLUTIONS.pdf. https://doi.org/10.5772/63176

Baharom Bakar. (2021, May 31). Telur tamat tempoh punca kes keracunan puding buih. Bharian.Com.My.

Chai, L. T., \& Yat, D. N. C. (2019). Online Food Delivery Services : Making Food Delivery the New Normal. Journal of Marketing Advances and Practices, 1(1).

Department of Islamic Development Malaysia (JAKIM). (2020). Malaysian Manual Procedure for Halal Certification. In Manual Procedure for Malaysia Halal Certification (Forth Revision): Vol. Forth.

Department of Standards Malaysia. (2009). MS 1500:2009: Halal Food - Production, Preparing, Handling and Storage - General Guidelines (Second Revision) (pp. 1-18). Department of Standards Malaysia.

Fuseini, A., Wotton, S. B., Knowles, T. G., \& Hadley, P. J. (2017). Halal Meat Fraud and Safety Issues in the UK: a Review in the Context of the European Union. Food Ethics, 1(2). https://doi.org/10.1007/s41055-017-0009-1

Halal Management Division of JAKIM. (n.d.). Halal History. Halal Malaysia Official Portal.

Islamic Tourism Centre. (2021, May 29). Malaysia - The World’s Leading Halal Hub. Itc.

Jakim. (2014). Manual Procedure for Malaysia Halal Certification (Third Revision) 2014. Manual Procedure, 67.

Kedah, Zulkarnain, Ismail, Y., Ahasanul Haque, A. k. M., \& Ahmed, S. (2015). Key Success Factors of Online Food Ordering Services: An Empirical Study. Malaysian Management Review, 50(2), 19-36.

Li, C., Mirosa, M., \& Bremer, P. (2020). Review of online food delivery platforms and their impacts on sustainability. In Sustainability (Switzerland) (Vol. 12, Issue 14). https://doi.org/10.3390/su12145528

Mat Nayan, N., \& Hassan, M. K. A. (2020). Customer satisfaction evaluation for online food service delivery system in Malaysia. Journal of Information System and Technology Management, 5(19). https://doi.org/10.35631/jistm.5190010

Mohamad Razif. (2017, February 7). Irsyad al-Fatwa Siri ke-170: Persoalan Berkenaan Uber dan Ubereats. Irsyad Al-Fatwa.

Nabilah. (2021). Rider seberang longkang sampai makanan jatuh, "Kenapa mesti lompat." Webpage.

Nina Naquiah Ahmad Nizar and Siti Aimi Sarah Zainal Abidin. (2021). Online Food Delivery Services-Make or Break the Halal Supply.pdf. Journal Of Food and Pharmaceutical Sciences, 9(1), 384-394

Noorsiah Ahmad, \& Sariwati Mohd Shariff. (2016). Factors Influencing Sertu Cleansing Integrity in Halal Logistics. Journal of Business and Accounting, 6(1).

Nurul Amanina Suhaini. (2017, July 17). 4 kontena daging kambing campur babi dirampas. Berita Harian Online.

Pitchay, A. A., Ganesan, Y., Zulkifli, N. S., \& Khaliq, A. (2021). Determinants of customers' intention to use online food delivery application through smartphone in Malaysia British Food Journal. https://doi.org/10.1108/BFJ-01-2021-0075

Sim Y. H. (2018, April 26). Restoran disabitkan kesalahan langgar perintah halal. Mediapermata.Com.

Sin, K.-Y., \& Lo, M.-C. (2021). The Determinants and Barriers of Outsourcing Third-Party Online Delivery: Perspectives of F\&B Entrepreneurs in Malaysia*. Abang Azlan MOHAMAD / Journal of Asian Finance, 8(5).

Statista.com. (2021, October). Online Food Delivery - Malaysia. Market Directory.

Suhaniza Said. (2021, May 21). Peka, bukan rasis! Peguam kongsi kisah adik ipar rela tak ambil makanan dipesan selepas rider beri info meragukan - "Rasa was-was tak boleh dalam Islam." Mstar.Com.My.

Tan, D. (2019). Food delivery firm delivers on growth. The Star Online, 11-14.

Yuchen, G. (2020). Factors Affecting Online Food Quality Control among Delivers in Delivery Process in Malaysia. IOSR Journal of Business and Management, 22(5).

Zalina Zakaria. (2004). Keberkesanan undang-undang makanan dan produk Halal di Malaysia. Jurnal Shariah, 12(2). 